\title{
Lithium Insertion into Vanadium Pentoxide Xerogels Containing Some Metal Cations
}

\author{
Yasushi KATAYAMA, * Yukako FuKUCHI, and Takashi MIURA \\ Department of Applied Chemistry, Faculty of Science and Technology, Keio University (Hiyoshi 3-14-1, Kohoku-ku, \\ Yokohama 223-8522, Japan)
}

Received June 3, 2003 ; Accepted August 5, 2003

\begin{abstract}
Vanadium pentoxide $\left(\mathrm{V}_{2} \mathrm{O}_{5}\right)$ xerogels containing some foreign metal cations, $\mathrm{Na}^{+}, \mathrm{Ca}^{2+}$ and $\mathrm{La}^{3+}$, have been prepared by ion-exchange of hydroxonium ions, $\mathrm{H}_{3} \mathrm{O}^{+}$, and investigated as a cathode material for rechargeable lithium battery. The discharge capacities of the cation-exchanged $\mathrm{V}_{2} \mathrm{O}_{5}$ xerogels are identical to that of $\mathrm{V}_{2} \mathrm{O}_{5}$ xerogel containing $\mathrm{H}_{3} \mathrm{O}^{+}$ at low current density. However, the capacities of the cation-exchanged $\mathrm{V}_{2} \mathrm{O}_{5}$ xerogels became lower than that of $\mathrm{V}_{2} \mathrm{O}_{5}$ xerogel containing $\mathrm{H}_{3} \mathrm{O}^{+}$with an increase in current density, suggesting the columbic interaction between the foreign metal cations and lithium ions hinders the diffusion of lithium ions between the layers.
\end{abstract}

Key Words : Vanadium Pentoxide Xerogel, Ion-exchange, Rechargeable Lithium Battery, Cathode Material

\section{Introduction}

Vanadium pentoxide $\left(\mathrm{V}_{2} \mathrm{O}_{5}\right)$ xeroge ${ }^{11}$ has a unique layered structure, ${ }^{2,3)}$ of which the interlayer distance is much larger than that of orthorhombic $\mathrm{V}_{2} \mathrm{O}_{5}{ }^{4}$ due to the existence of water molecules trapped between the layers by van der Waals interaction. ${ }^{5-7}$ ? The interlayer distance of $\mathrm{V}_{2} \mathrm{O}_{5}$ xerogel is determined by the amount of water molecules, which can be removed by elevating temperature. This wide interlayer distance is expected to be advantageous to the diffusion of lithium ions when $\mathrm{V}_{2} \mathrm{O}_{5}$ xerogel is used as a cathode active material of rechargeable lithium batteries. However, water molecules can be liberated from $\mathrm{V}_{2} \mathrm{O}_{5}$ xerogel and dissolve in the organic electrolytes. The contamination of water in the aprotic organic electrolytes leads to the degradation of anode materials and the decline of the cell capacity. On the other hand, elimination of water molecules results in a shrinkage of the interlayer distance of the $\mathrm{V}_{2} \mathrm{O}_{5}$ xerogel. Thus, it is desirable to remove water molecules from $\mathrm{V}_{2} \mathrm{O}_{5}$ xerogel with keeping the wide interlayer distance.

It has been well recognized that $\mathrm{V}_{2} \mathrm{O}_{5}$ xerogel contains from 0.3 to 0.4 moles of hydroxonium ions, $\mathrm{H}_{3} \mathrm{O}^{+}$, per $\mathrm{V}_{2} \mathrm{O}_{5}$. The hydroxonium ions can be exchanged with foreign metal cations by immersing $\mathrm{V}_{2} \mathrm{O}_{5}$ xerogel in the aqueous solution containing the metal cations. ${ }^{8-10)}$ Although the metal cations are introduced as the hydrated metal ions, ${ }^{11)}$ it is possible to remove water molecules from the hydrated metal cations by elevating temperature. In this study, we prepared water-free $\mathrm{V}_{2} \mathrm{O}_{5}$ xerogels containing some metal cations having different charges, $\mathrm{Na}^{+}, \mathrm{Ca}^{2+}$ and $\mathrm{La}^{3+}$, of which the crystallographic ionic radii are close to each other $(0.114-0.117 \mathrm{~nm})$. The electrochemical insertion of lithium into the cationexchanged $\mathrm{V}_{2} \mathrm{O}_{5}$ xerogels was examined in order to clarify the effects of the introduced metal cations on the kinetic and thermodynamic properties of $\mathrm{V}_{2} \mathrm{O}_{5}$ xerogels.

\section{Experimental}

A vanadate sol was prepared by acidification of sodium metavanadate $\left(\mathrm{NaVO}_{3}\right.$, Kanto Chemical) solution treated with ion exchange resin (Dowex $50 \mathrm{~W}$ ). The sol was settled for more than 2 weeks, allowing to gelling. The gel was dried at $60-90^{\circ} \mathrm{C}$ in the air to yield yellowish brown $\mathrm{V}_{2} \mathrm{O}_{5}$ xerogel. The content of water in $\mathrm{V}_{2} \mathrm{O}_{5}$ xerogel was controlled by heating either in the air or under vacuum at various temperature.

The cation-exchanged $\mathrm{V}_{2} \mathrm{O}_{5}$ xerogel was prepared by immersing $\mathrm{V}_{2} \mathrm{O}_{5}$ xerogel in the metal nitrate, $\mathrm{NaNO}_{3}$ (Kanto Chemical), $\mathrm{Ca}\left(\mathrm{NO}_{3}\right)_{2}$ and $\mathrm{La}\left(\mathrm{NO}_{3}\right)_{3}$ (Junsei Chemical), aqueous solution for 20 minutes with moderate agitation. The concentration of the metal nitrate was $0.1 \mathrm{M}$. The color of $\mathrm{V}_{2} \mathrm{O}_{5}$ xerogel changed as soon as $\mathrm{V}_{2} \mathrm{O}_{5}$ xerogel powder was added to the solution. The precipitated cation-exchanged $\mathrm{V}_{2} \mathrm{O}_{5}$ xerogel was filtered and dried at $90^{\circ} \mathrm{C}$ in the air. The amount of water contained in the cation-exchanged $\mathrm{V}_{2} \mathrm{O}_{5}$ xerogel was controlled in the same way as described above. All the dried $\mathrm{V}_{2} \mathrm{O}_{5}$ xerogel and the cation-exchanged $\mathrm{V}_{2} \mathrm{O}_{5}$ xerogel were handled in a glovebox (Miwa Seisakujo, 1ADB-2 + MM2-P $15 \mathrm{~S})$ of dry argon atmosphere with water concentration of less than $800 \mathrm{ppb}$ to avoid hydration of the samples in the air.

\section{1 Characterization of the samples}

The crystal structures of the samples were determined by X-ray powder diffraction (XRD) with the aid of Rigaku apparatus (RAD-C) using $\mathrm{Cu} \mathrm{K} \alpha$ radiation with a graphite monochrometer. The dried samples were mounted in an air-tight sample holder to avoid hydration of moisture in the air during the measurement. Thermal gravimetory and thermal differential analysis (TG-DTA, Mac Science, MTC-1000) were performed to determine the water contents and crystallization temperatures of the samples. The compositions of the samples were determined by 


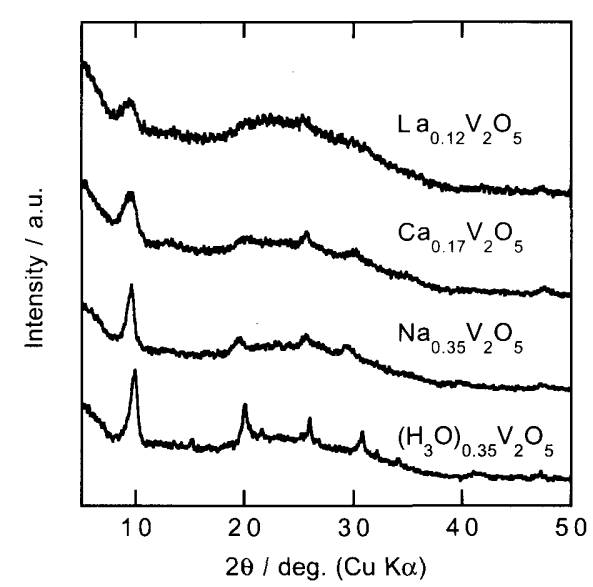

Fig. 1 XRD patterns of $\mathrm{M}_{y} \mathrm{~V}_{2} \mathrm{O}_{5}\left(\mathrm{M}=\mathrm{H}_{3} \mathrm{O}^{+}, \mathrm{Na}^{+}, \mathrm{Ca}^{2+}\right.$ and $\left.\mathrm{La}^{3+}\right)$ dried under vacuum at $150\left(\mathrm{H}_{3} \mathrm{O}^{+}\right)$or $250{ }^{\circ} \mathrm{C}$. The measurements were conducted under $\mathrm{Ar}$ atmosphere with an air-tight sample holder.

Table 1 Composition and interlayer distance $\left(c_{0}\right)$ of the cation-exchanged $\mathrm{V}_{2} \mathrm{O}_{5}$ xerogerls, $\mathrm{M}_{y} \mathrm{~V}_{2} \mathrm{O}_{5} \cdot n \mathrm{H}_{2} \mathrm{O}$.

\begin{tabular}{ccccc}
\hline $\mathrm{M}$ & $y$ & $n$ & $c_{0} / \mathrm{nm}$ & Drying temp. $/{ }^{\circ} \mathrm{C}$ \\
\hline $\mathrm{H}_{3} \mathrm{O}^{+}$ & 0.35 & 0.46 & 0.86 & 150 \\
$\mathrm{Na}^{+}$ & 0.35 & 0.13 & 0.87 & 250 \\
$\mathrm{Ca}^{2+}$ & 0.17 & 0.26 & 0.88 & 250 \\
$\mathrm{La}^{3+}$ & 0.12 & 0.20 & 0.87 & 250 \\
\hline
\end{tabular}

EPMA (Shimazu, EPMA-8705).

\section{2 Electrochemical measurements}

The mixture of powdered polytetrafluoroethylene (PTFE, Daikin), acetilene black (Denki Kagaku Kogyo) and the sample at the ratio of $10: 30: 60$ was pressed on $\mathrm{Ni}$ mesh at $200 \mathrm{kgf} \mathrm{cm}^{-2}$ to give a sample electrode. Lithium wires were used as the reference and counter electrodes. $1 \mathrm{M} \mathrm{LiClO}_{4} /$ propylene carbonate (PC) solution (Kishida Chemical) was used as electrolyte solution. Galvanostatic discharge and charge were performed by Multi-Potentiostat/Galvanostat (Toho Giken, PS-08) at $25^{\circ} \mathrm{C}$. All the potentials are presented against $\mathrm{Li} / \mathrm{Li}^{+}$potential.

\section{Results and Discussion}

The hydroxonium ions in $\mathrm{V}_{2} \mathrm{O}_{5}$ xerogel were exchanged successfully with $\mathrm{Na}^{+}, \mathrm{Ca}^{2+}$ and $\mathrm{La}^{3+}$. By means of EPMA analysis of the cation-exchanged samples, the amounts of $\mathrm{Na}^{+}, \mathrm{Ca}^{2+}$ and $\mathrm{La}^{3+}$ per $\mathrm{V}_{2} \mathrm{O}_{5}$ were found to be $0.35,0.17$ and 0.12 , respectively, which were consistent with the amount of hydroxonium ions in $\mathrm{V}_{2} \mathrm{O}_{5}$ xerogel, 0.35 , determined by thermal gravimetry. Figure 1 shows the XRD patterns of the cation-exchanged $\mathrm{V}_{2} \mathrm{O}_{5}$ xerogel, $\mathrm{M}_{\mathrm{y}} \mathrm{V}_{2} \mathrm{O}_{5}\left(\mathrm{M}=\mathrm{H}_{3} \mathrm{O}, \mathrm{Na}\right.$, $\mathrm{Ca}$ and $\left.\mathrm{La}\right)$ samples dehydrated by vacuum drying at $150^{\circ} \mathrm{C}$ for $\left(\mathrm{H}_{3} \mathrm{O}\right)_{0.35} \mathrm{~V}_{2} \mathrm{O}_{5}$ and $250^{\circ} \mathrm{C}$ for the others. The XRD patterns of the samples were similar to that of $\mathrm{V}_{2} \mathrm{O}_{5}$ xerogel, indicating the samples have a layered structure with randomly oriented $\mathrm{V}_{2} \mathrm{O}_{5}(a-b)$ planes. ${ }^{2,3)}$ The peak near $10^{\circ}$ for each sample corresponds to the 001 diffraction, of which the position reflects the interlayer distance. The calculated interlayer distances of the samples were within the range of

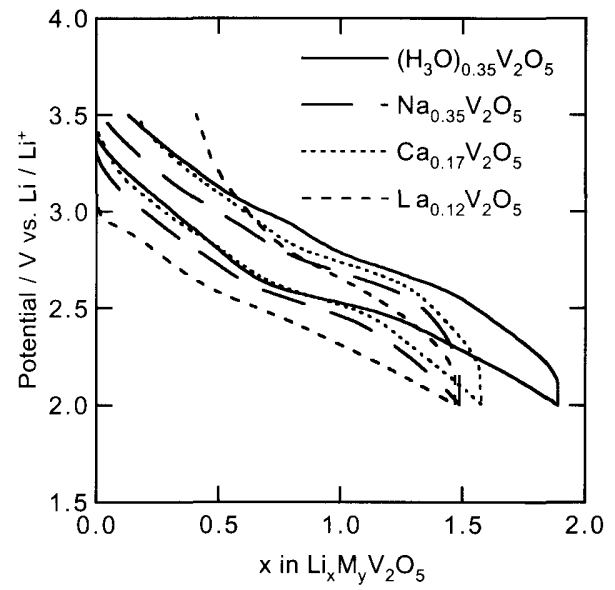

Fig. 2 Discharge-charge curves of $\mathrm{M}_{y} \mathrm{~V}_{2} \mathrm{O}_{5}\left(\mathrm{M}=\mathrm{H}_{3} \mathrm{O}^{+}, \mathrm{Na}^{+}\right.$, $\mathrm{Ca}^{2+}$ and $\left.\mathrm{La}^{3+}\right)$ in $1 \mathrm{M} \mathrm{LiClO}_{4} / \mathrm{PC}$ at $200 \mu \mathrm{A} \mathrm{cm}{ }^{-2}$.

$0.86-0.88 \mathrm{~nm}$, suggesting the interlayer distance is determined mainly by the size of the cation. The composition and interlayer distance of the samples are listed in Table 1. The samples contained a small amount of water, which is bonded strongly to vanadium atom of $\mathrm{V}_{2} \mathrm{O}_{5}$ layers and can not be removed with keeping semi-crystalline xerogel structure.

Figure 2 shows the discharge-charge curves of the dried $\mathrm{M}_{y} \mathrm{~V}_{2} \mathrm{O}_{5}\left(\mathrm{M}=\mathrm{H}_{3} \mathrm{O}, \mathrm{Na}, \mathrm{Ca}\right.$ and $\left.\mathrm{La}\right)$ samples at 200 $\mu \mathrm{A} \mathrm{cm}^{-2}$. For every sample, the potential decreased gradually with an increase in the extent of inserted lithium, $x$ in $\mathrm{Li}_{x} \mathrm{M}_{y} \mathrm{~V}_{2} \mathrm{O}_{5}$, without any distinct plateau. ${ }^{12)}$ However, the slope of the discharge curve became slightly smaller after the extent of inserted lithium exceeded $\sim 0.7$ per $\mathrm{M}_{4} \mathrm{~V}_{2} \mathrm{O}_{5}$. This change in the slope probably means there are at least two kinds of the sites accommodating lithium ions. The $x$ value until $2.0 \mathrm{~V}$ cut-off for $\left(\mathrm{H}_{3} \mathrm{O}\right)_{0.35} \mathrm{~V}_{2} \mathrm{O}_{5}$ was the lager than the other cationexchanged samples under the current density of $200 \mu \mathrm{A}$ $\mathrm{cm}^{-2}$ while the interlayer distances of all the samples were close to each other.

Figure 3 shows the dependence of the $x$ value until 2.0 $\mathrm{V}$ cut-off, $x_{\max }$, on the reciprocal of the current density. The $x_{\max }$ value reached to $\sim 2.0$ for every sample at low current density, indicating the $x_{\max }$ value is dependent on the current density and determined presumably by some kinetic factors, such as the diffusivity of lithium ions between the layers. There is a tendency that the difference in the $x_{\max }$ values for the cation-exchanged samples from $\left(\mathrm{H}_{3} \mathrm{O}\right)_{0.35} \mathrm{~V}_{2} \mathrm{O}_{5}$ increases with an increase in the current density. As seen in Fig. 2, the discharge curves for $x<$ $\sim 0.7$ are almost identical to each other, suggesting the interaction between the exchanged cations and lithium ions would appear considerably for $x>\sim 0.7$. In the cases of $\mathrm{Ca}^{2+}$ and $\mathrm{La}^{3+}$, the columbic interaction between these multivalent cations and lithium ion is expected to be strong, so that the diffusivity of lithium ions in the layers would deteriorate. In the case of $\mathrm{Na}^{+}$, however, the columbic interaction of lithium ions with $\mathrm{Na}^{+}$seems to be stronger than that with $\mathrm{H}_{3} \mathrm{O}^{+}$while the ionic radii of these cations are close to each other. This difference may be attributed to the ion-exchange of $\mathrm{H}_{3} \mathrm{O}^{+}$with $\mathrm{Li}^{+}$, 


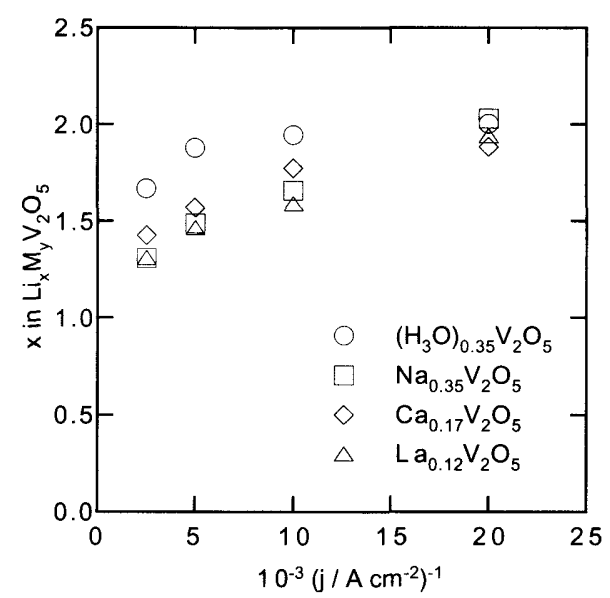

Fig. $3 x$ in $\mathrm{Lix}_{x} \mathrm{M}_{y} \mathrm{~V}_{2} \mathrm{O}_{5}\left(\mathrm{M}=\mathrm{H}_{3} \mathrm{O}^{+}, \mathrm{Na}^{+}, \mathrm{Ca}^{2+}\right.$ and $\left.\mathrm{La}^{3+}\right)$ until the cut off potential of $2.0 \mathrm{~V}$ in $1 \mathrm{M} \mathrm{LiClO}_{4} / \mathrm{PC}$ at various current densities.

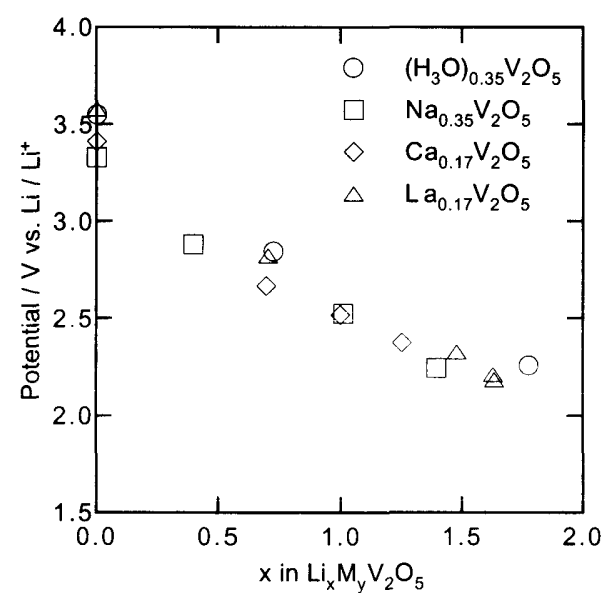

Fig. 4 Open circuit potentials of $\mathrm{Li}_{x} \mathrm{M}_{y} \mathrm{~V}_{2} \mathrm{O}_{5}\left(\mathrm{M}=\mathrm{H}_{3} \mathrm{O}^{+}, \mathrm{Na}^{+}\right.$, $\mathrm{Ca}^{2+}$ and $\mathrm{La}^{3+}$ ) in $1 \mathrm{M} \mathrm{LiClO}_{4} / \mathrm{PC}$.

presumably solvated by organic molecules, in the electrolyte solution.

The open circuit potentials of the samples at various $x$ values are shown in Fig. 4. There is no significant difference among the samples, indicating the ion-exchanged cations does not affect the redox potential between pentavalent and tetravalent vanadium atoms in the $\mathrm{V}_{2} \mathrm{O}_{5}$ layers. Thus, the difference observed on the discharge curves in Fig. 2 is ascribed possibly to the columbic interaction between the ion-exchanged cations and lithium ions.

\section{Conclusion}

$\mathrm{V}_{2} \mathrm{O}_{5}$ xerogels containing some foreign metal cations with a small amount of water molecules have been prepared and examined as the cathode material for rechargeable lithium battery. It was suggested that the interlayer distances of $\mathrm{V}_{2} \mathrm{O}_{5}$ xerogels can be controlled by introduction of foreign metal cations having different ionic radii. Although the columbic interaction between the foreign metal cations and lithium ions will lower the diffusivity of lithium ions between the layers compared to $\mathrm{V}_{2} \mathrm{O}_{5}$ xerogel containing hydroxonium ions, the contamination of water into the electrolyte solution can be minimized without shrinkage of the interlayer distance.

\section{Acknowledgements}

This work was partly supported by Grant-in-Aid for the 21st Century COE program "KEIO Life Conjugate Chemistry" from the Ministry of Education, Culture, Sports, Science, and Technology, Japan.

\section{References}

1) P. Aldebert, N. Baffier, N. Gharbi, and J. Livage, Mater. Res. Bull., 16, 669 (1981).

2) J. J. Legendre and J. Livage, J. Colloid Interface Sci., 94, 75 (1983).

3) J. J. Legendre, P. Aldebert, N. Baffier, and J. Livage, $J$. Colloid Interface Sci., 94, 84 (1983).

4) H. G. Bachman, F. R. Ahmed, and W. H. Barnes, $Z$. Kristallogr., 115, 110 (1961).

5) T. Miura, C. Takahara, and T. Kishi, Denki Kagaku (presently Electrochemistry), 59, 149 (1991).

6) J. F. Hazel and R. Santini, J. Phys. Chem., 57, 681 (1953).

7) J. Lemerle, L. Nejem, and J. Lefebvre, J. Inorg. Nucl. Chem., 42, 17 (1980).

8) D. Lemordant, A. Bouhaouss, P. Aldebert, and N. Baffier, J. Chim. Phys., 83, 105 (1986).

9) L. Znaidi, N. Baffier, and M. Huber, Mater. Res. Bull., 24, 1501 (1989).

10) N. Baffier, L. Znaidi, and M. Huber, Mater. Res. Bull ., 25, 705 (1990).

11) N. Baffier, L. Znaidi, and J-C. Badot, J. Chem. Soc. Faraday Trans., 86, 2623 (1990).

12) T. Kishi and M. Eguchi, Kagaku Kogyo, 46, 894 (1995). 